\title{
Implementation of Hypnobreastfeeding Therapy as an Effort to Reduce the Incidence of Underweight on Children Aged 0-6 Months
}

\author{
Nur Laily ${ }^{1 *}$, Fauzie Rahman ${ }^{1}$, Andini Octaviana Putri $^{2}$, Meitria Syahadatina Noor ${ }^{2}$, Atikah Rahayu $^{3}$, Fahrini Yulidasari ${ }^{3}$, \\ Lia Anggraini ${ }^{3}$, Vina Yulia Anhar ${ }^{4}$, Ayu Riana Sari ${ }^{2}$, Dian Rosadi ${ }^{5}$, Afifah Afifah $^{6}$, Muhammad Azmiannoor ${ }^{6}$, Bohari Bohari $^{7}$ \\ ${ }^{1}$ Department of Health Policy Administration, Public Health Study Program, Faculty of Medicine, Lambung Mangkurat University, \\ Banjarmasin, Indonesia; ${ }^{2}$ Department of Maternal and Child Health and Reproductive Health, Public Health Study Program, \\ Faculty of Medicine, Lambung Mangkurat University, Banjarmasin, Indonesia; ${ }^{3}$ Department of Nutrition, Public Health Study \\ Program, Faculty of Medicine, Lambung Mangkurat University, Banjarmasin, Indonesia; ${ }^{4}$ Department of Health Promotion, \\ Public Health Study Program, Faculty of Medicine, Lambung Mangkurat University, Banjarmasin, Indonesia; ${ }^{5}$ Department of \\ Epidemiology, Public Health Study Program, Faculty of Medicine, Lambung Mangkurat University, Banjarmasin, Indonesia; \\ ${ }^{6}$ Department of Health Policy Administration, Public Health Study Program, Faculty of Medicine, Lambung Mangkurat University, \\ Banjarmasin, Indonesia; ${ }^{7}$ Department of Nutrition, Faculty of Medicine, Universitas Sultan Ageng Tirtayasa, Serang, Indonesia
}

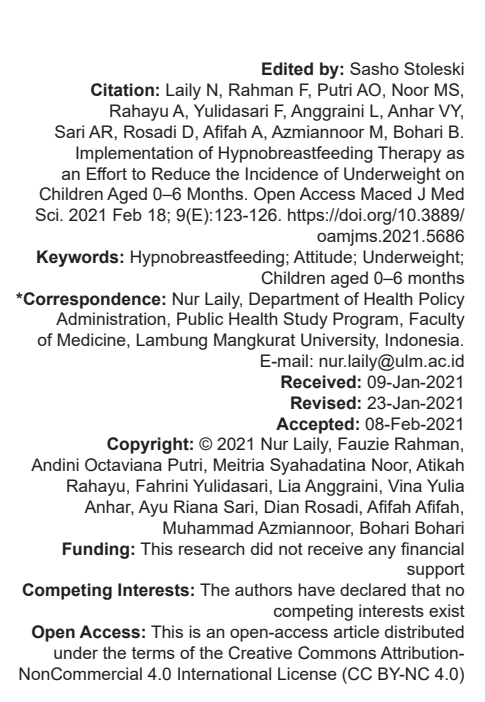

Abstract

AIM: This study aims to identify implementation of hypnobreastfeeding therapy as an effort to reduce the incidence of underweight on children aged 0-6 months.

METHODS: This study is a pre-experimental with pre-test and post-test design. Subjects were children aged 0-6 months who are underweight. The intervention was conducted over 2 months. Data were analyzed by univariate analysis using frequency distribution table and bivariate using McNemar test.

RESULTS: Before the education through hypnobreastfeeding therapy, only $33.3 \%$ of women having a good attitude about exclusive breastfeeding to children. After the intervention for 2 months, the percentage of good attitude increase as many as $73.3 \%$ and the mother is encouraged to continue to breastfeed the child obtained that a total of 18 children $(60 \%)$ of the total 30 children aged $0-6$ months are underweight, which has been entered into the category of normal nutritional status. A difference in the attitude of breastfeeding and status of underweight children aged $0-6$ months before and after implementation of hypnobreastfeeding therapy $(p<0.000)$

CONCLUSION: There are differences in the attitude of the breastfeeding mother $(p=0.012)$ and underweight status of children aged $0-6$ months $(p=0.000)$ before and after the implementation of hypnobreastfeeding therapy.

\section{Introduction}

One of the strategic health issues of the children is the problem of undernutrition and malnutrition. Children who are said undernutrition to be those that have a low weight that does not correspond to their age [1]. The World Health Organization 2017 report the number of children who are underweight (wasting) as many as 91.4 million people or $13.5 \%$ [2]. The prevalence of malnutrition among children under five is high in Indonesia at $17.7 \%$ [3]. Community diagnosis results in the field practice learning activity in 2018 in 17 villages in Karang Intan showed that the highest prevalence of underweight cases occurred in the Sungai Alang village by $37.5 \%$ consisting of $7.8 \%$ undernutrition and $29.7 \%$ malnutrition, whereas the majority of the people in Sungai Alang village have fishponds that should fulfilled family nutrition, especially mothers should be met properly.

One of the factors that influence the incidence of underweight toddler mainly in children aged 0-6 months is inadequate breastmilk obtained by the child due to his lack of awareness of mothers to breastfeed exclusively. The milk does not come out, the mother does not know the correct way to breastfeed, less confidence, or lack of self-confidence [4], [5]. Psychological aspects of the mother with the support of her husband and family had considerable influence in the success of exclusive breastfeeding. Confidence and the mother's intention to breastfeed their babies may increase the hormones prolactin and oxytocin which serves for the production and breastmilk expenditure. Unfortunately, not all mothers have a calm and positive mind. Therefore, 
one treatment efforts through the implementation of hypnobreastfeeding [6], [7].

Hypnobreastfeeding therapy do using relaxation techniques to reduce anxiety and stress of the mother, which can increase milk production. This way do by inserting sentences positive affirmations that help breastfeeding mothers while in a state of relaxed. Hence, the mindset of the mother would be made more positive and confident [8], [9]. Another study shows that there hypnobreastfeeding influence on the attitudes of pregnant women in exclusive breast feeding so as to improve the children nutrition status [10].

This study aims to identify implementation of hypnobreastfeeding therapy as an effort to reduce the incidence of underweight on children aged 0-6 months in Sungai Alang village, Karang Intan, Banjar.

\section{Methods}

This study is a pre-experiment research with one group pre and post-test design that aims to identify differences in attitudes in breastfeed mothers and underweight status of children aged 0-6 months after the implementation of hypnobreastfeeding therapy. The research was conducted in Sungai Alang village, Karang Intan, Banjar. Subjects in this study were mothers who had toddler (0-6 months) with underweight status of 30 people. The variables measured in this study are the attitude of breastfeed mothers and the status of underweight children aged 0-6 months. Instruments in this study are a questionnaire to measure the attitude of breastfeeding mothers and scales to measure the weight. Data were analyzed by univariate analysis by frequency distribution table and bivariate using McNemar test to determine differences in attitudes and underweight status of children aged 0-6 months before and after the implementation of hypnobreastfeeding therapy.

\section{Results}

Table 1 showed before the education through hypnobreastfeeding therapy only $33.3 \%$ of women having a good attitude about exclusive breastfeeding to children. After the intervention for 2 months, the percentage of good attitude increase as many as $73.3 \%$ so that it can be concluded that an increase in the attitude of the mother by $40 \%$ after a given intervention. Giving intervention in this study conducted in children who are recorded as having underweight as many as 30 people. Based on the Table 1, it is known that after the intervention for 2 months, the mother is encouraged
Table 1: Frequency distribution of mother's attitude and underweight status

\begin{tabular}{llllll}
\hline Variable & \multicolumn{1}{l}{ Before } & & & After & \\
\cline { 2 - 3 } & $\mathrm{n}$ & $\%$ & & $\mathrm{~N}$ & $\%$ \\
\hline Attitude & 20 & 66.7 & & 8 & 26.7 \\
$\quad$ Less & 10 & 33.3 & & 22 & 73.3 \\
Good & & & & 12 & 40 \\
Underweight status & 30 & 100 & & 18 & 60 \\
$\quad$ Underweight & 0 & 0 & & 18 \\
$\quad$ Normal & & & & \\
\hline
\end{tabular}

to continue to breastfeed the child obtained that a total of 18 children $(60 \%)$ of the total 30 children aged $0-6$ months are underweight, which has been entered in the category of normal nutritional status (Table 1).

Table 2: Differences attitudes before and after implementation of hypnobreastfeeding therapy

\begin{tabular}{|c|c|c|c|c|}
\hline \multirow[t]{2}{*}{ Attitude before } & \multicolumn{2}{|c|}{ Attitude after } & \multirow[t]{2}{*}{ Total } & \multirow{2}{*}{$\mathrm{p}$-value } \\
\hline & Less & Well & & \\
\hline Less & 4 & 16 & 20 & 0.012 \\
\hline Good & 4 & 6 & 10 & \\
\hline
\end{tabular}

The results showed a difference in the attitude of breastfeeding before and after implementation of hypnobreastfeeding therapy $(p=0.012)$ (Table 2) and there are differences in the status of underweight children aged 0-6 months before and after the application of hypnobreastfeeding therapy $(p=0.000)$ (Table 3).

Table 3: Difference underweight status of children aged 0-6 months before and after implementation hypnobreastfeeding therapy

\begin{tabular}{lllll}
\hline Before & After & & Total & p-value \\
\cline { 2 - 3 } & Underweight & Normal & & \\
\hline Underweight & 12 & 18 & 30 & 0.000 \\
Normal & 0 & 0 & 0 & \\
\hline
\end{tabular}

\section{Discussion}

Underweight is the nutritional status of a combination of under nourishment and severe malnutrition based on anthropometric indicators weight for age (W/A) [11] [12]. Underweight (underweight) is a condition where a person has a body weight whose body mass index is below normal. Weight conditions below the minimum threshold at high risk to the infection disease [13]. The incidence of underweight in children aged 0-6 months which one can be caused due to inadequate breastfeeding due to his lack of awareness of the mother or other problems from the aspect of physical and psychological aspects of motherhood [14].

Hypnobreastfeeding therapy is one of the efforts to return the mother willingness to breastfeed and produces sufficient milk. Hypnobreastfeeding done using relaxation techniques to reduce anxiety and stress in the mother, which can increase milk production. In this research, the way with education in the mother and by giving sentences positive affirmations that help breastfeeding mothers while in a state of relaxed or very concentrated on one thing (hypnosis). Hence, the 
mother will be more positive attitude, confident, and smooth breastmilk spending and to support the growth of children [8], [15], [16].

The results showed a difference in the attitude of breastfeeding before and after implementation of hypnobreastfeeding therapy $(p=0.012)$. Attitude is person closed response to a stimulus or object. Steps in changing attitudes, attention, and understanding of the subject to the stimulus can be either communication or messages being delivered. Research about attitude is considered attractive because considered can predict human behavior in the future [17]. Implementation of hypnobreastfeeding not only relaxation to breastfeeding mothers but also accompanied by the provision of information or education in breastfeeding mothers on exclusive breastfeeding. The results showed a difference in the attitude of mother after the implementation of the intervention. There was an increase of $40 \%$ mother attitude. The previous research conducted by Ernawati (2016) showed that education giving related to the mother's breast milk can significantly improve the attitude of the mother in breastfeeding exclusively to her child [18].

Mothers who attend the class discussion and education about breastfeeding increases their opportunity to make exclusive breastfeeding. A comprehensive breastfeeding education intervention is an attempt to improve the success of exclusive breastfeeding. These interventions are expected to support the formation of mothers attitudes then the good attitude that expected to support the success of a mother breastfeeding her baby so that it can fulfilled the nutritional needs of infants and can achieve optimal weight in accordance with the aged [19].

The implementation of hypnobreastfeeding therapy showed a significant difference in the increase in body weight of children aged 0-6 months $(p=0.000)$. Hypnobreastfeeding predicted influences the success of exclusive breastfeeding at $7 \%$ that the end result is the fulfillment of the nutritional status of children [10]. Through this intervention is expected to help mothers in breastfeeding. Providing exclusive breastfeeding properly, the nutritional needs of children will be fulfilled and have a positive impact on changes in children's body weight. Research conducted by Endarwati and Sukoharjo (2018) showed that there was a relationship between breastfeeding with a weight gain of children aged 6 months $(p=0.015)$ [20]. According the theory, nutritional influence on growth even in the womb though. The child weight gain is strongly influenced when the child is getting adequate food intake, food energy needed by the child for the purposes of basal metabolism, growth, and activity. Exclusively breastfed infants have a better nutritional status of infants nonexclusive breastfeeding. That is because breast milk is the main food, the best, and the first natural for babies to be given without other foods until the age of 6 months. Because breastmilk contains immune substances, anti-infective, and nutrients that the baby needs to achieve optimal growth and development. Exclusively breastfed infants have a better nutritional status of infants non-exclusive breastfeeding. That is because breast milk is the main food, the best, and the first natural for babies to be given without other foods until the age of 6 months. Because breastmilk contains immune substances, anti-infective, and nutrients that the baby needs to achieve optimal growth and development.

\section{Conclusion}

There are differences in attitude and status of underweight children aged 0-6 months before and after hypnobreatfeeding therapy. The recommendation of this study is the cooperation and support of all parties to ensure the success of the breastfeeding process. Providing education about breastfeeding can be carried out from pregnant women to breastfeeding mothers so that mothers can prepare themselves to breastfeed both physically and psychologically.

\section{Acknowledgments}

We would like to thanks all the participants who had participated in this study and grateful to the head of South Kalimantan province health office, head of district health office, and head of Puskesmas and all who had been helpful to us during the study period.

\section{References}

1. Ni'mah K, Nadhiroh SR. Factors related to the incidence of stunting in children under five years old. Med Gizi Indones. 2015;10:1-13. https://doi.org/10.31227/osf.io/d6pmq

2. World Health Organization. Global and Regional Trends by UN Regions, 1990-2030 Underweight: 1990-2019. Geneva: World Health Organization; 2018. Available: https://www.apps.who.int/ gho/data/view.main.NUTUNUNDERWEIGHTV?lang=en. [Last accessed on 2020 Nov 10].

3. Kementerian Kesehatan Republik Indonesia. Laporan Nasional Riskesdas 2018. Jakarta: Badan Penelitian dan Pengembangan Kesehatan; 2018. https://doi.org/10.31002/rep.v5i1.2050

4. Mulyani NS. ASI dan Pedoman Ibu Menyusui. $2^{\text {nd }}$ ed. Yogyakarta: Nuha Medika; 2013.

5. Syeda B, Agho K, Wilson L, Maheshwari GK, Raza MQ. Relationship between breastfeeding duration and undernutrition conditions among children aged 0-3 Years in Pakistan. Int $\mathrm{J}$ Pediatr Adolesc Med 2020;2020:1-6. https://doi.org/10.1016/j. ijpam.2020.01.006 
6. Wattimena I, Werdani YD, Novita BD, Dewi DA. Manajemen laktasi dan kesejahteraan ibu menyusui. J Psikol UGM. 2015;42(3):3. https://doi.org/10.22146/jpsi.9911

7. Yu J, Wells J, Wei Z, Fewtrell M. Effects of relaxation therapy on maternal psychological state, infant growth and gut microbiome: Protocol for a randomised controlled trial investigating motherinfant signalling during lactation following late preterm and early term delivery. Int Breastfeed J. 2019;14(1):50. https://doi. org/10.1186/s13006-019-0246-5

8. Sumawati NR, Yanti NM. Penerapan hypnobreastfeeding dan hypnoparenting pada ibu 2 jam post partum. J Dunia Kesehat 2016;5(2):76541.

9. Anuhgera DE, Kuncoro T, Sumarni S, Mardiyono M, Suwondo A. Effect of combination of hypnobreastfeeding and acupressure on anxiety and wound pain in post-caesarean mothers. Belitung Nurs J. 2017;3(5):5. https://doi.org/10.33546/bnj.191

10. Endah A. Pengaruh Hypnobreastfeeding Terhadap Keberhasilan Pemberian ASI Eksklusif di Rumah Sakit Panti Rapih Yogyakarta. Yogyakarta: Universitas Gadjah Mada; 2015. https://doi.org/10.15416/ijcp.2014.3.3.67

11. Kementerian Kesehatan Republik Indonesia. Buku Saku Pemantauan Status Gizi Tahun 2017. Jakarta: Direktorat Gizi Masyarakat Dirjen Binkesmas; 2018.

12. Mukabutera A, Thomson DR, Hedt-Gauthier BL, Basinga $P$, Nyirazinyoye L, Murray M. Risk factors associated with underweight status in children under five: An analysis of the 2010 Rwanda Demographic Health Survey (RDHS). BMC Nutr. 2016;2(1):40. https://doi.org/10.1186/s40795-016-0078-2

13. Supariasa ID, Bakri B, Fajar I. Penilaian Status Gizi. Jakarta: EGC; 2010.

14. de Pereira TA, Freire AK, Gonçalves VS, de Pereira TA, Freire AK, Gonçalves VS. Exclusive breastfeeding and underweight in children under six months old monitored in primary health care in Brazil, 2017. Rev Paul Pediatr. 2020;39:2019293. https://doi. org/10.1590/1984-0462/2021/39/2019293

15. Masruroh N, Andriani RA. Effect of Hypno Breastfeeding on Colostrum Ejection Onset in Primiparous Mothers. Proceeding $4^{\text {th }}$ International Conference Public Health, Aug. 2018. Available from: http://www.theicph.com/id_ID/2018/09/19/ effect-of-hypno-breastfeeding-on-colostrum-ejection-onset-inprimiparous-mothers. [Last accessed on 2020 Sep 11]. https:// doi.org/10.26911/theicph.2018.03.26

16. Ningsih F, Lestari RM. Efektifitas Kombinasi Pijat Oksitosin dan Hypno Breastfeeding terhadap Optimalisasi Produksi ASI pada Ibu Nifas. J Surya Med 2019;5(1):958. https://doi.org/10.33084/ jsm.v5i1.958

17. Notoatmodjo S. IImu Perilaku Kesehatan. Vol. 200. Jakarta: Rineka Cipta; 2010.

18. Ernawati B. Peningkatan pengetahuan, sikap dan tindakan ibu dalam memberikan asi eksklusif melalui edukasi kelompok. J IImu Keperawatan. 2016;4(2):2. Available: http://www.erepository.unsyiah.ac.id/JIK/article/view/6387. [Last accessed on 2020 Sep 11]. https://doi.org/10.31219/osf.io/mc47b

19. Ambarwati MR, Setiyani A, Usnawati $N$. The effectiveness of breastfeeding discussion classes as a health promotion medium in improving breastfeeding practice. J Kesehat. 2017;10(1):22.

20. Endarwati D, Sukoharjo TS. Hubungan pemberian asi eksklusif dengan berat badan bayi usia 6 bulan di posyandu desa mulur, bendosari, sukoharjo relation the provision of exclusive breastfeeding to baby weight age 6 months at posyandu village of Mulur, Bendosari, Sukoharjo. Indones J Med Sci 2020;5(1):1. Available from: http://www.ejournal.ijmsbm.org/index.php/ijms/ article/view/136. [Last accessed on 2020 Sep 11]. https://doi. org/10.37831/jik.v5i1.112 